\title{
WAYS OF IMPROVEMENT OF ECOLOGICAL POLICY IN THE ACTIVITY OF MOTOR VEHICLES TECHNICAL SERVICE COMPANIES IN UKRAINE
}

\author{
Liudmyla Savchenko \\ Ph.D., Assistant Professor, Polissia National University, Ukraine \\ e-mail: slgua@ukr.net, orcid.org/0000-0002-7689-4982 \\ Vasyl Savchenko \\ Ph.D., Assistant Professor, Polissia National University, Ukraine \\ e-mail: dgs-ua@ukr.net, orcid.org/0000-0002-0921-1424
}

\section{Summary}

The purpose of the article is revealing the basics of environmental policy formation at technical service companies. The article considers the peculiarities of the concept of environmental policy, its goals and objectives; identifies the ecological aspects of activity of the company of technical vehicle service, the most essential of them; it shows the role of the management of the company in implementation of ecological policy. The ecological policy of the company is realized through its performance of ecological function. That is, the introduction of a system of measures aimed at improving the ecological condition of the environment. By pursuing a clearly defined and effective environmental policy, the company, if not enlarging, but shall increase its profits.

It is proved that the development of an effective environmental policy is one of the first and most responsible steps in creating an environmental management system at the company of technical service. It plays an important role in determining the priorities of the company and should have specific environmental goals and objectives. In fact, environmental policy determines the degree of environmental responsibility and the extent of the obligations of the company of technical service to the environment, according to which all its subsequent actions will be evaluated.

Keywords: ecological safety, environment, company of technical service, ecological aspects, ecological policy.

DOI: https://doi.org/10.23856/4435

\section{Introduction}

In modern conditions, there is an increased interest of companies of technical service of motor transport to the introduction and certification of environmental management system in accordance with ISO 14000. An important step in the formation of the environmental management system at the motor vehicles technical service companies is the development of environmental policy, which determines the main direction of its activities in the environmental field in the long run and, ultimately, ensures the achievement of environmental goals and objectives.

\section{Analysis of recent researches and publishing}

Problems related to the development and implementation of environmental policy at companies in various sectors of the economy have been studied by such well-known foreign 
and domestic scientists as O. Balatskyi, T. Halushkin, A. Enders, R. Yefremova, L. Zhubanova, V. Ihnatov, A. Kokin, L. Melnyk, Yu. Satalkin, S. Khamzyna, A. Khachapurov, V. Shevchuk, I. Yaremchuk, M. Yatskiv and others. At the same time, despite numerous scientific investigations, the issues of development and implementation of environmental policy at technical service companies remain understudied.

Purpose of the article is revealing the basics of environmental policy formation at technical service companies.

\section{Main material}

The ecological policy of the companies is implemented through its performance of ecological function. Thus, according to the current legislation of Ukraine and its ratified international standards (ISO 9000 and ISO 14000), the concept of "environmental policy" is defined as follows - it is "the general intentions and focus of the company on its environmental characteristics, officially declared by top management" (DSTU ISO 14001:2015). That is, it is a certain system of measures aimed at improving the ecological condition of the environment.

Yu.V. Babina defines the environmental policy of the company as a set of generally declared principles and obligations related to the environmental aspects of the company, providing a basis for establishing and achieving its own environmental goals and objectives (Babina, 2017:33).

Unfortunately, a significant number of business leaders still believe that the development and implementation of environmental policy reduces the company's profits, as it requires significant investment (and thus increase costs, and profits do not reach their maximum level). However, we believe, this is a false statement, because it is through a clearly defined and effective environmental policy that the company, if not maximized, will increase its profits, that's for sure.

V.V. Savran notes that the leveling of environmental problems, on the contrary, leads to negative externalities in the environment, which, in turn, has a negative impact on the functioning of the company and reduces its profits. And this happens for the following reasons:

firstly, the increase in emissions into the atmosphere (or into the surrounding water bodies) increases the morbidity of workers and their families, and as a result the payments increase for hospital payments and the release of the required number of products or services. And even if the employee continues to work, in an unfavorable environmental situation, its productivity will decrease, and in the long run there may be a situation where the descendants of these workers will be unable to work at all, and the company will have to attract labor from other regions. to increase costs;

secondly, the introduction of more environmentally friendly production will reduce the risk of accidents, reduce depreciation of fixed assets and increase their useful life;

thirdly, the quality of products and services of the company will increase and as a result consumer loyalty will increase, and consequently, sales will increase (the result is an increase in production, cost reduction and profit maximization);

fourth, for foreign investors, the important factor is that the company is socially responsible and implements a certain environmental policy. Therefore, they will be more willing to invest in such companies (and these funds, in turn, can be used to modernize and further expand production) (Savran, 2017).

O.V. Bohuslavskyi adds that in the conditions of high technology development a modern company needs to use environmental policy in order to demonstrate its own environmental responsibility and environmental security (Savran, 2017). 
O.V. Barabash, studying the activities of companies of technical service of motor transport, noted that in order to justify and start implementing environmental policy at the company, it is necessary to consider the input parameters of the technological process - waste, emissions, water, electricity, gas, gasoline, diesel fuel etc., as well as the initial parameters of the system of the technological process - compliance with the limits of use of water, electricity, gas, gasoline, diesel fuel, compliance with the MPC in the formation of emissions, waste (Barabash, 2010:72).

Based on the input and output parameters of the process system O.V. Barabash identified ecological aspects of activity of the company of technical service of motor transport and created their register - the table 1.

Table 1

\section{Ecological aspects of activity of companies of technical service of motor transport (Barabash, 2010:73).}

\begin{tabular}{|c|c|c|}
\hline Activity, process, service & Aspect (terms of formation) & Environmental impact \\
\hline 1 & 2 & 3 \\
\hline $\begin{array}{l}\text { Replacement of rechargeable } \\
\text { batteries }\end{array}$ & $\begin{array}{l}\text { Sulfuric acid leakage, evap- } \\
\text { oration of sulfuric acid } \\
\text { vapors, irrational use of water } \\
\text { resources }\end{array}$ & $\begin{array}{l}\text { Soil and water pollution, air } \\
\text { pollution, depletion of water } \\
\text { resources }\end{array}$ \\
\hline Welding metals & $\begin{array}{l}\text { Accumulation of welding wire, } \\
\text { release of pollutants into the } \\
\text { atmosphere }\end{array}$ & $\begin{array}{l}\text { Soil pollution, accumulation of } \\
\text { solid waste, air pollution }\end{array}$ \\
\hline $\begin{array}{l}\text { Maintenance of engine } \\
\text { engines, including boring, } \\
\text { grinding, honing of engine } \\
\text { cylinders and boring of } \\
\text { crankshafts }\end{array}$ & $\begin{array}{l}\text { Release of pollutants into the } \\
\text { atmosphere, waste generation }\end{array}$ & $\begin{array}{l}\text { Atmospheric air pollution, soil } \\
\text { pollution }\end{array}$ \\
\hline $\begin{array}{l}\text { A set of works on wheel } \\
\text { replacement, installation and } \\
\text { dismantling of tires }\end{array}$ & Accumulation of used tires & $\begin{array}{l}\text { Contamination of soils with used } \\
\text { tires, irrational use of land plots. }\end{array}$ \\
\hline Body repair & $\begin{array}{l}\text { Formation of solid waste, metal } \\
\text { dust, use of water resources }\end{array}$ & $\begin{array}{l}\text { Soil pollution by scrap metal- } \\
\text { metal ingress into the soil, } \\
\text { accumulation of scrap metal, } \\
\text { air pollution, depletion of water } \\
\text { resources }\end{array}$ \\
\hline Repair of vehicles & Waste generation & $\begin{array}{l}\text { Contamination of soils with } \\
\text { scrap metal and harmful sub- } \\
\text { stances }\end{array}$ \\
\hline $\begin{array}{l}\text { Technical inspection of motor } \\
\text { vehicles }\end{array}$ & Waste generation & $\begin{array}{l}\text { Contamination of soils with } \\
\text { consumables }\end{array}$ \\
\hline Repair of bus parts & $\begin{array}{l}\text { Solid waste generation, use of } \\
\text { water resources }\end{array}$ & $\begin{array}{l}\text { Contamination of soils with } \\
\text { metal shavings and scrap metal, } \\
\text { depletion of water resources }\end{array}$ \\
\hline $\begin{array}{l}\text { Priming and painting of } \\
\text { vehicles }\end{array}$ & $\begin{array}{l}\text { Formation of solid waste and } \\
\text { paint vapors entering the air, } \\
\text { use of water resources }\end{array}$ & $\begin{array}{l}\text { Air pollution, soil pollution by } \\
\text { waste from paints, depletion of } \\
\text { water resources }\end{array}$ \\
\hline
\end{tabular}


Table 1 (Continued)

\begin{tabular}{|l|l|l|}
\hline \multicolumn{1}{|c|}{1} & \multicolumn{1}{|c|}{2} & \multicolumn{1}{c|}{3} \\
\hline $\begin{array}{l}\text { Vulcanization of damaged } \\
\text { tires and cameras }\end{array}$ & $\begin{array}{l}\text { Formation of solid waste and } \\
\text { vapors of glue and heated rubber }\end{array}$ & Soil and air pollution \\
\hline $\begin{array}{l}\text { Disassembly and repair work, } \\
\text { assembly, control and test } \\
\text { of the check point, steering, } \\
\text { brake system units }\end{array}$ & $\begin{array}{l}\text { Evaporation of crankcase } \\
\text { gases, leakage of oil and lubri- } \\
\text { cants, formation of solid waste }\end{array}$ & $\begin{array}{l}\text { Atmospheric air pollution, soil } \\
\text { and water pollution }\end{array}$ \\
\hline $\begin{array}{l}\text { Check of vehicles for service- } \\
\text { ability by a smoke meter and } \\
\text { a gas analyzer }\end{array}$ & $\begin{array}{l}\text { Excessive emissions of exhaust } \\
\text { gases into the atmosphere }\end{array}$ & Atmospheric air pollution \\
\hline
\end{tabular}

Based on these tables, we distinguish four groups of environmental pollutants as a result of the activities of the company of technical service of motor transport:

- emissions of harmful substances from exhaust gases;

- ingress of chemical elements into the air due to welding and other works;

- losses of substances used in production processes;

- waste generation;

- wastewater is contaminated with chemical compounds.

Based on the definition of such significant environmental aspects, the company of technical service of motor transport should develop its environmental policy, because it, in accordance with the nature and scale of the impact of production activities on the environment, determines the most important environmental aspects of technical service, and includes goals and commitments. in the field of its constant improvement and prevention of pollution.

The environmental policy of the technical service company is based on the following principles and obligations. (Semenova, 2012:102):

- rational use of resources;

- priority of planned and implemented actions and measures related to prevention (prevention) of impact on the environment, before measures and actions to minimize and eliminate the consequences of such impact;

- health and safety of the personnel of the company of car service and the population;

- consistent continuous improvement of characteristics and indicators of impact of the carried-out activity, production and services on environment and consumption of resources with orientation on the level of development of technics and technology and a condition of development of a society formed at a concrete stage of scientific and technical progress;

- mandatory compliance with the requirements of environmental legislation, including international agreements, Ukrainian state and local legislation, sectoral regulatory requirements, as well as other regulatory requirements governing the activities of technical service companies;

- adoption and implementation of any management and production decisions, taking into account the environmental aspects of future activities, products and services provided;

- consistent involvement and motivation (training, encouragement, responsibility) of all staff in environmental activities;

- informing and maintaining an open dialogue with all interested in the environmental aspects of the technical service company and the results of the assessment of its impact on the environment;

- understanding the priorities of systemic environmental management in the field of environmental protection and the desire for consistent implementation of international management standards. 
Yu.O. Nikolaev names the main purposes of ecological policy of the companies of technical service (Nikolaiev, 2008:140): companies;

- achieving a level of environmental safety that meets the performance of the best

- increase of ecological safety of the company, decrease in influence on environment at the expense of increase of reliability, maintenance of safe and trouble-free work of the technological equipment;

- prevention and minimization of quantity and toxicity of emissions, discharges of pollutants and wastes at increase in production volumes at the expense of introduction of new technologies, the equipment, materials and increase of level of automation of management of technological processes;

- introduction of effective technical solutions and technologies to minimize and eliminate the level of environmental pollution.

In modern conditions the ecological policy of the companies of technical service of motor vehicles should correspond to their scale and the nature of influence on environment. Among the set of measures, the environmental policy of such an company should include statements about the compliance of its activities with environmental standards, the sustainable improvement of the environmental management system, as well as measures to prevent pollution.

L.A. Mochalova adds that the following factors should be taken into account in the framework of environmental policy (Mochalova, 2008:207):

- regional and local conditions of activity;

- assessment and reduction of any negative impacts of the technical service company on various aspects of the environment (land, water, air, flora and fauna, etc.);

- energy management, resource conservation and energy selection;

- management of use of raw materials, optimization of a choice of its kind and conditions of transportation;

- management of use and protection of water resources;

- reduction of waste generation, their secondary use, transportation and utilization of waste;

- assessment and reduction of intensity of harmful physical influences in the territory of the company and outside it;

- selection of new production processes and changes in existing production processes;

- planning of products/services (design, production, packaging, transportation, use and disposal of waste) from the standpoint of environmental protection;

- determining the impact of the practical activities of contractors, subcontractors and suppliers on the indicators of environmental degradation;

- prevention and restriction of emergency situations;

- ecological education and training on environmental issues;

- external information on environmental issues.

The environmental policy of each technical service company of motor transport should be developed independently and periodically revised taking into account results of checks, audit and the analysis. The ecological policy of the company is made out in the form of the document which is brought to the notice of all employees of the company and is accessible to the public.

The top management is responsible for the development and adoption of the environmental policy of the company of technical service of motor transport. As a rule, the implementation of environmental safety policy is carried out either by the director himself or directly by the person authorized in the field of environmental protection (technical director, chief engineer, etc.). The head of the technical service company (Shvydanenko, 2017:69): 
- organizes development, provides implementation and necessary adjustment of ecological policy of the company;

- organizes activity on observance by employees of the company of the state nature protection legislation, regulatory legal acts of local self-government, instructions of the state supervision authorities;

- determines the responsibilities of the heads of structural units of the technical service company (or a specially authorized employee) responsible for environmental safety;

- approves the internal documents governing the environmental activities of the technical service company.

The person directly authorized in the field of environmental protection, in turn:

- organizes and ensures the implementation of environmental policy and the most important environmental goals;

- organizes compliance of production, products and services with the requirements of relevant standards, rules and norms of environmental protection and rational use of natural resources;

- organizes and ensures the planning of environmental activities aimed at achieving the approved environmental goals of the relevant targets and targets for all major environmental aspects of production, products and services; programs;

- manages the development, reviews, approves and adjusts environmental plans and

- organizes the development and implementation of advanced systems and forms of organization of work on environmental protection;

- controls the provision of the main specialists of compliance of production technology, equipment, buildings and structures with the requirements of standards, rules and norms of environmental protection;

- monitors the implementation of employees of the company rules, orders of the head;

- manages the development, organizes the consideration and approval in the prescribed manner of organizational and technical measures to improve the environmental situation, organizes control over their implementation;

- periodically checks the organization of work on environmental protection in the structural units of the company;

- conducts testing of knowledge in the field of environmental protection;

- ensures the formation of environmental training plans for employees;

- organizes the development and implementation of forms and systems of incentives (incentives) for better work in the field of environmental protection;

- organizes and provides a regular process of environmental monitoring and environmental audit;

- organizes and provides interaction between different levels of government, as well as relations with external stakeholders on environmental issues;

- carries out the general management of development and implementation of the normative-methodical documents regulating nature protection activity of the company of technical service (Shvydanenko, 2017:70).

The specific responsibilities of employees of the technical service company in the field of environmental protection are reflected in their job descriptions, taking into account the structure and specifics of production and economic activities of the company.

Environmental policy and its derivatives - internal normative-methodical, organizational documents of the technical service companies in the field of environmental protection are developed on the basis of international, state legislative and normative acts, taking into 
account the requirements established by local governments. structural subdivisions carry out their activities.

Internal documents, which are developed and adopted at the technical service company on the basis of environmental policy, should be aimed at:

- prevention of impact on the environment and on the consistent improvement of all environmental aspects of its activities, as well as to provide an opportunity to assess the impact on the environment and its condition;

- development, adoption and adjustment of environmental policy, goals and objectives; activities;

- planning, organization and practical implementation of environmental protection

- current monitoring and control of activity;

- audit of the environmental management system, analysis of the achieved results and improvement of the existing environmental management system (Holub, 2014: 10).

Implementation of the environmental policy of the technical service company requires compliance with the following requirements:

- introduction of the provision on constant improvement in the field of management of ecological activity and ecological policy of the company;

- documentation, implementation and communication to staff;

- compliance of the profile and scale of the company and the nature of the impact of its activities, products and services on the environment;

- establishing a framework for defining and reviewing environmental goals and objectives;

- access for the public;

- introduction of obligations to comply with laws, regulations and other requirements for which the company is responsible.

From the position of Yu.V. Babina environmental policy of the technical service company affects (Babina, 2017:35):

- responsibility (and its distribution) for environmental protection, based on the organizational structure of each technical service company;

- system of ecological training of the personnel of the technical service company, which will determine the categories of specialists and personnel whose activity affects the environment, categories of determining the need for training, the procedure for making decisions on referral to training, the procedure for checking the effectiveness of training (certification);

- system of stimulation of the personnel of the company of technical service concerning increase of professional skill and efficiency of nature protection activity;

- operational communication between different levels of the environmental management system;

- a system for handling documents that regulate or register all aspects of this activity. The system of document circulation in the field of environmental protection operates in accordance with internal regulations, as well as documents governing reporting to regulatory organizations;

- identification and control of operations affecting the environment. The order of operations management determines: procedures for identification of operations, identification of the most significant operations, determination of quantitative criteria of personnel work on operations in order to comply with the established planned environmental indicators, functional responsibility for compliance with the established requirements;

- system of prevention of emergencies and emergencies at technical service companies, including: procedures and methods for determining risks, emergencies, documentation of all 
emerging emergencies and emergencies, the procedure for personnel in case of emergencies and emergencies, action plan to prevent accidents and emergencies, etc.

The management of the technical service company before the beginning of implementation of ecological policy should understand that it is not something steady and invariable. Also, the actual process of practical implementation of environmental policy requires its improvement based on the achievement of the results of the company, taking into account the changing situation and the opportunities that open up.

\section{Conclusions}

The development of an effective environmental policy is one of the first and most responsible steps in creating an environmental management system at the company of technical service. It plays an important role in determining the priorities of the company and should have specific environmental goals and objectives. In fact, environmental policy determines the degree of environmental responsibility and the extent of the obligations of the technical service company to the environment, according to which all its subsequent actions will be evaluated.

\section{References}

Babina, Yu.V. (2017). Ekologicheskaya politika predpriyatiya v sovremennyh usloviyah hozyajstvovaniya [Environmental policy of the enterprise in modern economic conditions]. Ekologiya proizvodstva. [in Russian]

Barabash, O. V. (2010). Identyfikatsiia ekolohichnykh aspektiv ta stvorennia ekolohichnoi polityky dlia avtotransportnoho pidpryiemstva [Identification of environmental aspects and creation of environmental policy for the transport company]. Kyiv: Visnyk Natsionalnoho transportnoho universytetu. [in Ukrainian]

Holub S.H. (2014). Mekhanizmy upravlinnia ekolohichnoiu bezpekoiu na pidpryiemstvi [Mechanism's of Environmental safety management at the enterprise]. Odesa: Prychornomorskyi ekolohichnyi biuleten. [in Ukrainian]

DSTU ISO 14001:2015. Systemy ekolohichnoho upravlinnia. Vymohy ta nastanovy shchodo zastosovuvannia (ISO 14001:2015, IDT) [Elektronnyi resurs] - Rezhym dostupu: http:// online.budstandart.com/ua/catalog/doc-page.html?id_doc $=64015$ [in Ukrainian]

Semenova, V.F., Mykhailyk, O.L. (2012). Ekolohichnyi menedzhment [Environmental management]. Kyiv : Znannia. [in Ukrainian]

Mochalova, L.A. (2008). Mehanizmy formirovaniya ekologicheskoj politiki i strategii promyshlennyh predpriyatij [Mechanisms for the formation of environmental policy and strategy of industrial enterprises]. Sumy: ehanizmy regulirovaniya ekonomiki. [in Russian]

Nikolaiev, Yu.O. (2008) Formuvannia systemy ekoloho-ekonomichnoho upravlinnia na vitchyznianykh pidpryiemstvakh [Formation of the system of ecological and economic management at domestic enterprises]. Dnipro: Ekonomichnyi visnyk NHU. [in Ukrainian]

Shvydanenko, H.O., Kryvoruchkina, O.V., Matukova, D.H. (2017) Rozvytok pidpryiemstva na ekoloho-ekonomichnykh zasadakh: monohrafiia [Development of the enterprise on ecological and economic bases]. Kyiv: KNEU. [in Ukrainian]

Savran, V.V., Bohuslavskyi, O.V., Savran, V.V. (2017) Ekolohichna polityka pidpryiemstva, yak osnovna skladova yoho ekonomichnoi stratehii [Environmental policy of the enterprise as the main component of its economic strategy] / [Elektronnyi resurs] - Rezhym dostupu: https:// core.ac.uk/download/pdf/324265887.pdf [in Ukrainian] 